\section{Sectoral diversification of UAE toward a knowledge-based economy}

Diversification toward knowledgebased economy

Shamim Ahmad Siddiqui

Hamdan Bin Mohammed Smart University, Dubai, United Arab Emirates, and

Munshi Naser Ibne Afzal

Department of Economics, Shahjalal University of Science and Technology, Sylhet, Bangladesh

\begin{abstract}
Purpose - The purpose of this study is to look at the United Arab Emirates' (UAE's) progress toward economic diversification and becoming a knowledge-based economy.

Design/methodology/approach - The World Development Indicators (WDI) and GlobalEconomy websites provided all secondary data for this paper. The data are largely used to highlight the UAE's current level of diversification and, consequently, the atmosphere for a knowledge economy transition necessary for sustainable development. Additionally, the study conducts a nonparametric estimation using DEA to identify the condition of four variables pertaining to the UAE's knowledge economy. The Herfindahl-Hirschman index (HHI) was utilized empirically in this study to determine the current state of diversity.

Findings - According to this research, the UAE economy was reasonably diverse until recently. The number of patents and journal papers published per resident both add to the UAE's GDP. Furthermore, the UAE's information and communication technology (ICT) exports are inconsistent; a declining trend in the number of researchers and the education sector's continuous struggles are major concerns. Furthermore, Figure 1 in the introduction reinforces this conclusion by noting that construction and building remained the greatest employer of labor throughout the time period. This is a significant finding because, as illustrated in this research, low labor force participation in the education sector, combined with lower citizen participation in advanced education in the UAE, results in low scientific research and publications, with low knowledge output as patent applications. In general, the majority of the UAE's population is expat, and the extent to which locals and expats contribute to the overall advancement of education remains an open question. According to the data envelopment analysis (DEA) model, three variables in the knowledge economy are productive, and they are economic incentive and institutional regime, innovation systems and ICT. The findings of this article will aid policymakers in the UAE, and more generally in the Gulf Cooperation Council (GCC) region, in developing more successful policies that help in the growth of a knowledge- and innovation-based economy.

Practical implications - This study is appropriate for UAE economic policymakers to monitor the state and policies required for the UAE's transition to a knowledge economy.
\end{abstract}

Originality/value - This issue has rarely been addressed by the use of robust parametric and nonparametric processes, as well as robust data visualization tools.

Keywords Knowledge economy, UAE, ICT, Innovation, Economic diversification, HHI, DEA

Paper type Research paper

(C) Shamim Ahmad Siddiqui and Munshi Naser Ibne Afzal. Published in Review of Economics and Political Science. Published by Emerald Publishing Limited. This article is published under the Creative Commons Attribution (CC BY 4.0) licence. Anyone may reproduce, distribute, translate and create derivative works of this article (for both commercial and non-commercial purposes), subject to full attribution to the original publication and authors. The full terms of this licence may be seen at http://creativecommons.org/licences/by/4.0/legalcode

JEL classification $-02,05$
Received 23 July 2021 Revised 10 January 2022 Accepted 2 February 2022 
REPS

7,3

\section{Introduction}

The emirates of Abu Dhabi, Dubai, Umm al-Quwain, Sharjah, Ras al-Khaimah, Ajman and Fujairah comprise the United Arab Emirates (UAE). Abu Dhabi, the UAE's largest emirate, has one of the world's largest oil and natural gas reserves. UAE has invested its economic revenues from oil in other industries, making it the seventh largest Arab economy and the 29th largest in the world (Phuong, 2020).

UAE is regarded as a high-performing economy in the GCC (Gulf Cooperation Council). It is ranked among the top 40 countries on the HDI (Human Development Index). Since the beginning of oil mining, it is attempting to diversify its economic reliance on oil. The oil sector will become less profitable in the future as a result of the gradual growth in renewable energy consumption, the depletion of efficient oil reserves and the fast fluctuation in oil prices (Elder and Serletis, 2010; Pickl, 2019; Güney, 2019). To this end, the UAE, along with the other GCC countries, is attempting to diversify its economy by focusing on knowledge and innovation (Ahmed and Abdalla Alfaki, 2013).

To achieve this level of economic development, however, three stages must be completed: (1) factor-driven growth, (2) efficiency-driven growth and (3) innovation-driven growth. A relatively small country in size and population, UAE has relied on foreign workers since its independence in 1971 from the British colonial rule. Fortunately, it possessed huge reserves of oil and gas, specially Abu Dhabi, the largest emirate. The hikes in the oil prices after the Arab-Israel War in 1973, and the after the Iranian Revolution in 1979, allowed UAE to import huge number of foreign workers, which has continued to date. Moreover, the oil revenue was used to immensely improve country's infrastructure. A very favorable environment was created for foreign and local investment. Unlike many of the developing countries, almost all government-owned enterprises were run on purely commercial basis, Emirates Airline being one example. Dubai, the second largest emirate, realizing that its oil reserve would be soon exhausted, launched a huge move toward economic diversification, largely through tourism and foreign investment in property.

The UAE has progressed to the investment stage and is now seeking to proceed to the knowledge/innovation stage. Prior to 2010, economic growth in the UAE was mostly driven by capital and labor accumulation rather than by efficiency in the utilization of production factors. It is currently undergoing a transition to a stage of efficiency to innovative growth. To examine the role of science, technology and innovation (STI) in the UAE's transition to a knowledge economy, one must first assess the country's progress in implementing the KE (knowledge economy) pillars. The country has been in the forefront in adapting new innovations and technologies. However, if we look at the sectoral contribution to its GDP, oil and construction remain dominant, while education and information technology still play an insignificant role. This situation must be changed through an integrated policy approach that considers the unique demographic, state and social structures of the country.

This paper analyzes UAE's achievements and shortcomings both in diversifying its economy and in its march toward becoming a knowledge-based economy.

This study is divided into seven pieces; section 2 contains literature analysis aimed at identifying gaps, while section 3 contains our approach for doing this research. Section 4 summarizes our findings by showing several critical factors, HHI and the results of a DEA technique. Sections 5-7 discuss and contribute to the discussion, conclude and provide policy recommendations, and discuss limitations and future work.

\section{Review of literature and some secondary data}

\subsection{Economic diversification}

Economic diversification is a technique for shifting an economy's reliance from a single source of income to several sources spread over the primary, secondary and tertiary sectors. 
Economic diversification aims to boost economic growth while ensuring long-term sustainability (UNFCC, 2018). Jones (2001, p. 360) suggests that diversification in an economy can be understood as activities and policies that an economy adopts to "[...] lower the economy's reliance on a small number of export commodities that are prone to price and volume swings or secular decreases." Economic diversification is important for countries where a big percentage of exports is concentrated on only a few items and services, according to the UNFCC (2018). Today, the UAE's main export commodities are crude oil and natural gas, and as explained by Sachs and Warner (2001), countries that specialize in natural resources are doomed to suffer from a resource curse. While there are differing academic views on whether the UAE suffers from the Dutch disease or not, the UNFCC (2018) diversification theory remains relevant to the UAE.

For the past 40 years, UAE, like other GCC countries, has faced the same dilemma. Natural resources are the principal source of revenue for all of them. Their people rely on their governments for social services and patronage. Furthermore, because significant sectors are state-owned and regulated, the private sector does not have much clout in the economy (Young, 2020). As described in the previous subsections, the UAE has experienced many oil shocks over the years as a hydrocarbon exporter. According to Haouas and Heshmati (2014), the country must diversify to avoid any long-term negative effects of sector concentration.

According to Mourdaa and Atyeh (2017), UAE has tried to invest their economic surpluses judiciously in growing other industries, especially since they have experienced several economic downturns due to oil price variations. It is investing in major economic cities, education, technology, financial services, tourism, enormous infrastructure projects and in building their sovereign wealth funds, according to the authors (Mourdaa and Atyeh, 2017). The tourism sector in the UAE has become very promising, with revenues of USD 43.3 billion, accounting for $12 \%$ of total GDP (UAE, 2021), with Abu Dhabi and Dubai focused on big infrastructure and seasonal projects. Furthermore, when it comes to the SWF (Sovereign Wealth Fund) sector, Young (2020) stated that the UAE's SWF is a major participant in the GCC; however, he cautioned governments against relying on SWF because returns are not always assured and can be delayed. The author also encouraged the UAE government to concentrate on domestic selfsufficiency and increase FDI. The UAE, on the other hand, has taken a number of initiatives to promote FDI through infrastructure development and trade liberalization (Alshamlan et al., 2021).

\subsection{Knowledge economy}

Overall, knowledge economy is an economic system that is directly based on the use of knowledge and information in the production and distribution process as a diversification option (Afzal and Siddiqui, 2009; Afzal and Lawrey, 2012c). Because of the ever-increasing returns to scale provided by the externalities of the stock of information and innovation, the knowledge economy differs from any other economic system (Afzal and Siddiqui, 2009; Afzal and Lawrey, 2012c). Furthermore, a knowledge-based society can generate new information based on previous experience, which can aid in making innovative judgments that result in resource efficiency (Schiliro, 2013). Because the concept of scarcity does not exist in a knowledge-based economy, it is distinguished from the traditional economic model (Afzal and Siddiqui, 2009). The stock of knowledge is the fundamental driver of the economy in a knowledge-based economy, and it is only via this process that a country's economic development can be sustained (Afzal and Lawrey, 2012b) (see Figure 2).

According to the World Bank, the knowledge economy is built on four pillars (Figure 3), hence any country attempting to create this model must guarantee that these pillars are in sync (Schiliro, 2013).
Diversification
toward
knowledge-
based economy

179 
REPS

7,3
The marginal cost of employing information or knowledge for other purposes is exactly zero once it has been collected through innovation and discovery. In the utilization of natural resources, there is a rental price; but, in a competitive market, the rental price of knowledge is low, and the value is near to zero (Afzal and Siddiqui, 2009). Furthermore, current growth economics, notably endogenous growth theory, has emphasized the shift to a knowledge economy via factor productivity and technological advancement (Schiliro, 2013). Thus, sustained economic progress through a knowledge-based economy necessitates innovation (Afzal and Lawrey, 2014), increased labor and capital productivity, and efficient use of existing knowledge (Afzal and Siddiqui, 2009).

\subsection{Performance of UAE in diversification and knowledge-based economy}

The UAE looks to have made substantial progress in terms of macroeconomic climate and infrastructure quality, particularly in the ICT sector, in implementing the KE pillars and transitioning to an innovation-driven stage. The knowledge economy index (KEI) was between 40 and 44 over the last decade (2010-2020) (according to globaleconomy.com); however, the movement has not been smooth. The index has been declining since 2018. The country has a lot of challenges that will require concerted effort and attentive monitoring. For instance, the UAE falls behind the bulk of transition economies and several GCC member states in terms of expenditure in education and research and development (Gulf News December, 2021). The country sends approximately 15,000 students abroad per year, a number that has been increasing at around 3-4\% per year. The US, UK and Canada are the most popular studyabroad destinations, but recently Germany, the Netherlands and Australia have emerged as high-growth destinations. The reasons are visa "friendliness" for Arab students, affordability and work-study pattern for other nationalities (Afzal and Siddiqui, 2009).

In the education sector, UAE is both a source and host market, with approximately 58,000 local and 80,000 international student enrolment, respectively (60\% of these are UAEbased residents). The country offers opportunities for international universities to set up branch campuses in Dubai or the UAE to get closer to their source markets. This becomes even more important in the post-covid world with travel and visa restrictions affecting international student enrolments in the US, UK, Canada, Australia and other popular Western higher education hubs (Abu Dhabi Awards Dh40 Million in Research Funding to 53 Projects, n.d.). However, the inward education hub is still struggling in UAE.

According to the Federal Competitiveness and Statistics Centre (FCSC), 2018-19, "administrative, Sharia and law specialists accounted for the largest percentage (42.1\%) of higher education students in the UAE. Next most numerous specialists are from engineering, industry and construction, totaling 66,748 students or $22.6 \%$. This is followed by social sciences, journalism and information specialists, with 28,485 students $(9.6 \%)$ [1]."

One has to also consider the unique character of UAE economy. The local population comprises only $18 \%$ of the total population of 10 million. Many of the foreign university students belong to white collar expatriate families who, for financial or social reasons, do not send their children abroad. There are also those who come to UAE to study at local campuses of foreign universities. A large number of graduates, after completing their studies, leave for higher education abroad or go back to their homeland. Indeed, a number of them seek jobs in UAE. The relatively higher standard of education and the immigration policies of the First World have much greater attraction, especially for the more talented ones. The UAE policy of long-term (golden) visa, especially to foreign students with good educational standing, is a major positive development and expected to bear fruits in the long run.

The above-mentioned obstacles lead to country's incapacity to absorb, adapt to and more importantly to develop new technologies and knowledge bases, which have a detrimental 
effect on the country's innovation score. As a result, the country's economy has a negative trade balance in terms of technology transfer from abroad. The approaches of comparative and situational analysis employed in this context resulted in the conclusion of numerous lessons and policy recommendations (Ahmed and Abdalla Alfaki, 2013).

Knowledge and innovation are viewed as the most critical variables for long-term economic progress and as a potential solution to the current impediment. The knowledge economy concept evolved from the link between knowledge and economy. It is distinct from a typical economic system in that it bases its production and distribution processes on knowledge and information. This economic transition toward the knowledge-based economy is a complete process that results in significant changes to the components of economic activity. Additionally, it necessitates highly skilled citizens capable of excelling in all sectors of the economy through increased productivity, a cooperative attitude, diversity and the generation of new information through research and innovation (Bashir, 2013).

In the context of the UAE, the majority of studies on economic diversification through knowledge use descriptive analysis based on secondary data (Parcero and Ryan, 2017; Phuong, 2020; Ahmed and Abdalla Alfaki, 2013; Ahmed, 2015; Schiliro, 2013). Parcero and Ryan (2017) stated that the UAE is performing well in the knowledge economy transition, but recommended that the innovation sector be strengthened. Phuong (2020) also expressed optimism about the UAE diversifying its economy and placing a premium on a green economy in addition to a knowledge-based economy. Ahmed and Abdalla Alfaki (2013) urged the UAE government to enhance spending on education, research and development in order to address the country's negative trade balance in foreign technology transfer. Overall, the authors expressed optimism about the UAE's progress toward a knowledgebased economy, with some urging the government to speed the process (Parcero and Ryan, 2017; Phuong, 2020; Ahmed and Abdalla Alfaki, 2013; Ahmed, 2015; Schiliro, 2013).

Only Qatar was 0.81 points ahead of the UAE in the KEI value between 1995 and 2012 among the Gulf countries, while the UAE only improved by 0.25 points. The UAE appears to rank well in terms of innovation and the four pillars of the knowledge economy (Ahmed and Abdalla Alfaki, 2013).

To integrate into an adaptive and highly trained flexible workforce, a knowledge economy requires labor with fresh ideas, skills and a high level of creativity (Schiliro, 2013). Studies show that, with the exception of one pillar of the knowledge economy, education, the UAE outperformed other Gulf countries (Ahmed and Abdalla Alfaki, 2013).

Furthermore, the ranking based on research and publication suggests that the government should devote more resources to higher education and research; the UAE was only mentioned in 12,914 research projects between 1996 and 2010, which is significantly less than South Korea, Singapore and Saudi Arabia (Ahmed and Abdalla Alfaki, 2013). However, according to a recent study by Phuong (2020), the UAE has recently prioritized its educational system. In 2019, it will devote almost half of its total government budget on science and technology-based training development for its inhabitants' social development. The most recent education strategy focuses on improving learning and developing excellent, university-eligible students so that they can compete in the global market (Phuong, 2020). The UAE has identified six areas of concern, including fair justice and public security, world-class health care, a sustainable environment and infrastructure, a world-class education system, a competitive knowledge economy and, finally, engaging societies and maintaining identities (Phuong, 2020).

It is also important to point out the relative size of the work force involved in the education sector, (see Figure 1) [2].

A comparison of the major fields in which UAE workers are engaged is provided in Figure 1, including the education sector. Throughout the period, the construction industry 


\section{REPS}

7,3

\section{2}

Figure 1.

Sectoral employment status in UAE

\section{Figure 2.}

The four pillars of the knowledge economy

\section{Foreign Labourers employed in UAE private sector by} activity (2004-2016, selected activities)
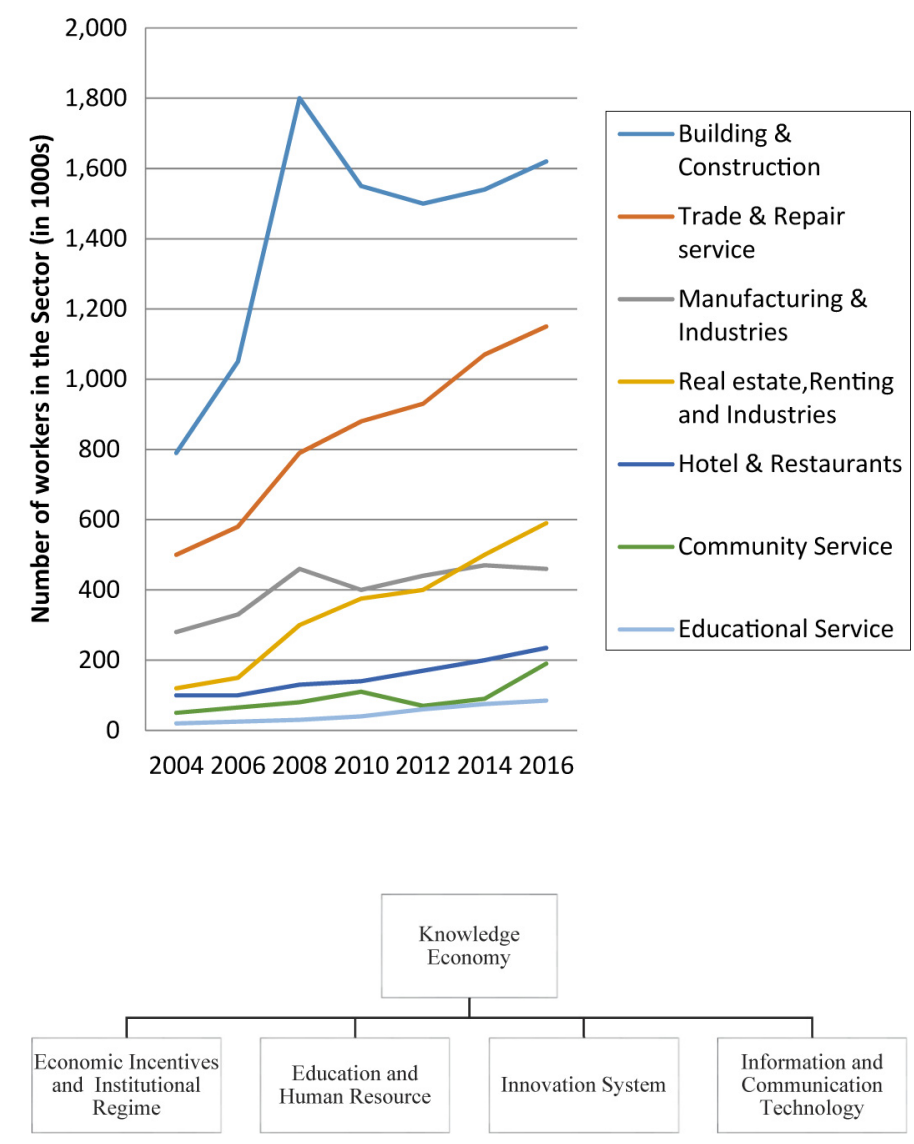

Figure 3.

Research publication from 1996 to 2010

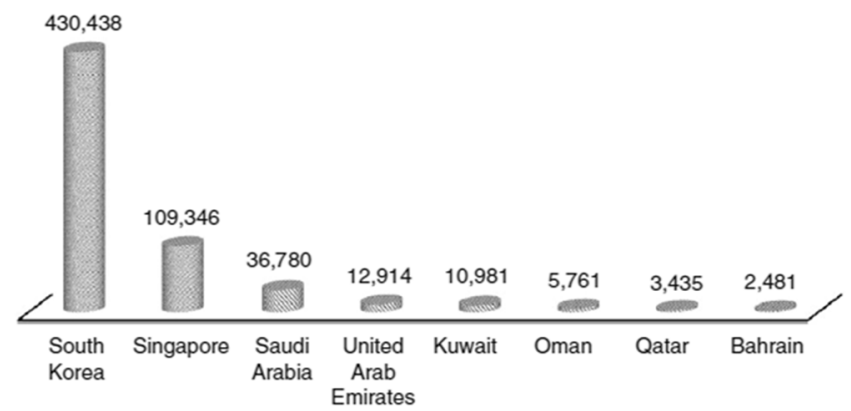


remained the largest employer of workers. Over time, trade and repair services have constantly created more and more job prospects for people. Real estate and industries, hotels and restaurants and community services were also performing well as compared to the educational service sector. On the other hand, educational services as a source of employment have remained virtually unchanged over time. In 2004, total employment in this industry was around 20,000, and after over a decade, in 2016, total employment in this sector was 85,000, which is quite low compared to any of the other sectors in this graph (Phuong, 2020).

\subsection{Research gap from literature review}

Because the existing literature lacks empirical analysis, this study has developed a twopronged strategy to filling this gap. We begin by determining the UAE's economic diversification state using the HHI (Herfindahl-Hirschman Index) and then using data envelopment analysis (DEA) to assess the knowledge economy efficiencies of various knowledge economy components.

The literature has examined the topic of economic diversification and the UAE's diversification initiatives in general. Among the promising industries, it is clear that diversifying toward a knowledge-based economy can help lessen its reliance on oil. Numerous empirical research on the knowledge economy have been conducted in both parametric (Shapira et al., 2006; Dima et al., 2018) and nonparametric (Afzal and Lawrey, 2012a, b, c) contexts outside of the GCC countries, including the UAE. Thus, no empirical studies on adapting to a knowledge economy for sectoral change in the UAE were identified; thus, we consider this as a substantial research agenda for this study.

To address this research gap, we have posed the following research questions, which are addressed in the study's subsequent sections:

(1) What is the UAE's economic diversification status?

(2) What is the efficiency ratio of the four components of the UAE's knowledge economy?

\section{Methodology design}

To broaden our knowledge, the paper primarily attempted to examine the connected factors by visualizing them in section 4.1 .

In section 4.3, we used the HHHI to determine the UAE's present economic diversification level in order to undertake a more precise analysis. Finally, in section 4.4, this research uses a nonparametric DEA model to calculate the efficiency of each knowledge economy factor.

\subsection{Herfindahl-Hirschman Index (HHI)}

The HHI, called after its first inventor Hirschman (1980) and its reinventor Herfindahl (1950), was initially used to examine a country's commerce, measuring the concentration of its export or import pattern over time. Furthermore, the Herfindahl-Hirschman method was frequently utilized by the United States Department of Justice in the 1980s to determine the extent of monopoly in an industry, and by the United Nations Conference on Trade and Development (UNCTAD) to determine the level of diversity in exports (Wadi and Bashayreh, 2018).

In this analysis, we used the gross fixed capital creation of $18 \mathrm{UAE}$ industries to quantify economic diversity. In this situation, the inverse of diversification is calculated using the HHI. The squared share of each sector in total gross capital creation is multiplied by two to get this concentration ratio (Canada, 2017). We utilize data from 2010 to 2017, and fixed
Diversification toward knowledgebased economy 
REPS

7,3

\section{4}

capital units are measured in million dirhams. In this calculation, we use 18 of the UAE sectors offered by Bayanat in our data set (2020). The following are the sectors:

(1) Nonfinancial corporations

(2) Agriculture, forestry and fishing

(3) Mining and quarrying (include crude oil and natural gas)

(4) Manufacturing

(5) Electricity, gas and water supply; waste management activities

(6) Construction

(7) Wholesale and retail trade; repair of motor vehicles and motorcycles

(8) Transportation and storage

(9) Accommodation and food service activities

(10) Information and communication

(11) Financial and insurance activities

(12) Real estate activities

(13) Professional, scientific and technical activities

(14) Administrative and support service activities

(15) Public administration and defense, compulsory social security

(16) Education

(17) Human health and social work activities

(18) Arts, recreation and other service activities

The equation can be expressed as:

$$
H H I=\sum_{i=1}^{N}\left(\frac{X_{i}}{X}\right)^{2}
$$

where:

$X_{i}$ is the gross fixed capital formation value of sector $i$;

$X$ is the total gross capital formation; and

$N$ is the total number of sectors.

We choose HHI because of its simplicity in implementation. Moreover, it considers more weight to its product with large shares by squaring before addition. This index has an upper bound (a perfect 1) and lower bound (near to zero or 1/N) (Cracau and Lima, 2016). The more the value of this index, the less diversified the economy is, and vice versa (Canada, 2017).

In this paper, we consider three categories of diversification, according to the value of HHI (Canada, 2017):

Diversified: $\mathrm{HHI}<0.15$.

Moderately diversified: $0.15<\mathrm{HHI}<0.25$.

Least diversified: $\mathrm{HHI}>0.25$.

3.2 DEA

DEA is a linear programming tool used in economics and other related sciences to compare a sector's efficiency to that of a reference sector (Afzal and Lawrey, 2012a). In general, this 
model's specialty is that it does not require any specific functional form; it may calculate each unit's single relative efficiency ratio by comparing total weighted outputs to total weighted inputs (Afzal and Lawrey, 2012a). It was created with the intention of measuring performance. It is a great technique for assessing a product's relative performance or technical efficiency across a set of companies (referred to as decision-making units in DEA) that use a variety of inputs and outputs.

The efficiency level of decision-making units (DMU) is compared to the best performer in the study to measure comparison performance. The DEA approach creates a single relative ratio for each DMU by comparing total weighted outputs to total weighted inputs. In the original Charnes, Cooper and Rhodes model, the DEA efficiency value varies from 0 to 1 (Charnes et al., 1978).

\subsection{Data sources}

There are essentially two sorts of data sources for the research study: primary and secondary sources. For the macro aspects of our data, we used a secondary data gathering approach, notably the World Development Indicator (WDI) data set.

Additionally, we have retrieved the WDIs for the DEA section by entering data for UAE, as well as the data period, which is 2000-2020. Additionally, we have used open-source public data of UAE to calculate HHI.

\section{Results}

With our secondary data, we attempt to infer the overall state of the UAE's knowledge economy in this section by visualizing various related variables and, additionally, establishing an intervariable comparison for greater comprehension in section 4.1. Afterward, we conduct an empirical assessment of the UAE's economic diversification in sections 4.2 and 4.3. Finally, we used DEA to deduce the current state of the UAE's knowledge economy by comparing their various efficiency in section 4.4.

\subsection{Data visualization analysis}

We can observe a comparison of the KEI and GDP in this bar chart. In 2008, the UAE's GDP was 315.475 billion USD, with a KEI value of 6.66. After four years, both the GDP and the KEI values increased to 374.591 and 6.94 billion USD, respectively (see Figure 4)

Figure 5 depicts the comparison of variables between the years 2017 and 2018, which shows very small changes. In 2018 , labor with a primary education increased, with a small

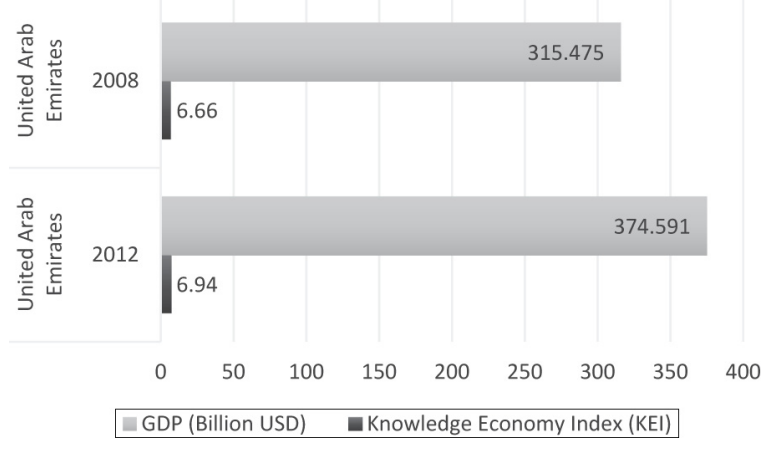

Figure 4 . Bar chart for GDP and KEI 


\section{REPS}

7,3

186

Figure 5.

Bars showing $\mathrm{HCI}$ and labor force with basic and advanced education
Figure 6.

Primary vs secondary education expenditure
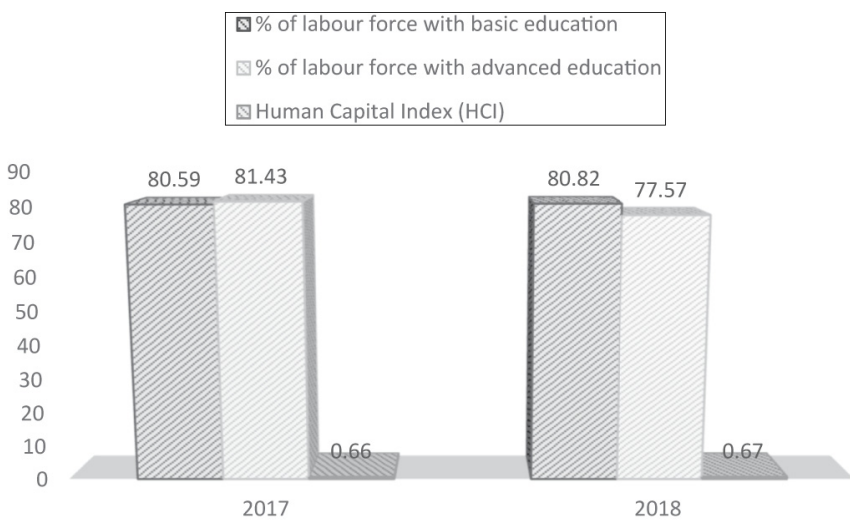

change in HCI, though labor with an advanced education decreased by $3.86 \%$, which is an important finding for the policymakers in UAE (see Figure 6).

As can be seen, primary education expenditure has always been higher than secondary education expenditure, though in 2013, secondary education expenditure (percent of total expenditure in secondary public institution) surpassed primary education expenditure (percent of total expenditure in secondary public institution).

Patent applications are increasing year after year, for both citizens and nonresidents. Though our data reveal that nonresidents file for patents more frequently than locals, we cannot draw any conclusions regarding the efficiency of these two categories because expats account for $88.52 \%$ of the UAE's overall population (GMI, 2021).

\subsection{Results of Herfindahl-Hirschman Index (HHI) analysis}

We utilize gross fixed capital formation data as a proxy for our economic diversity index in this brief analysis. Fixed capital formation data is considered an important indicator for

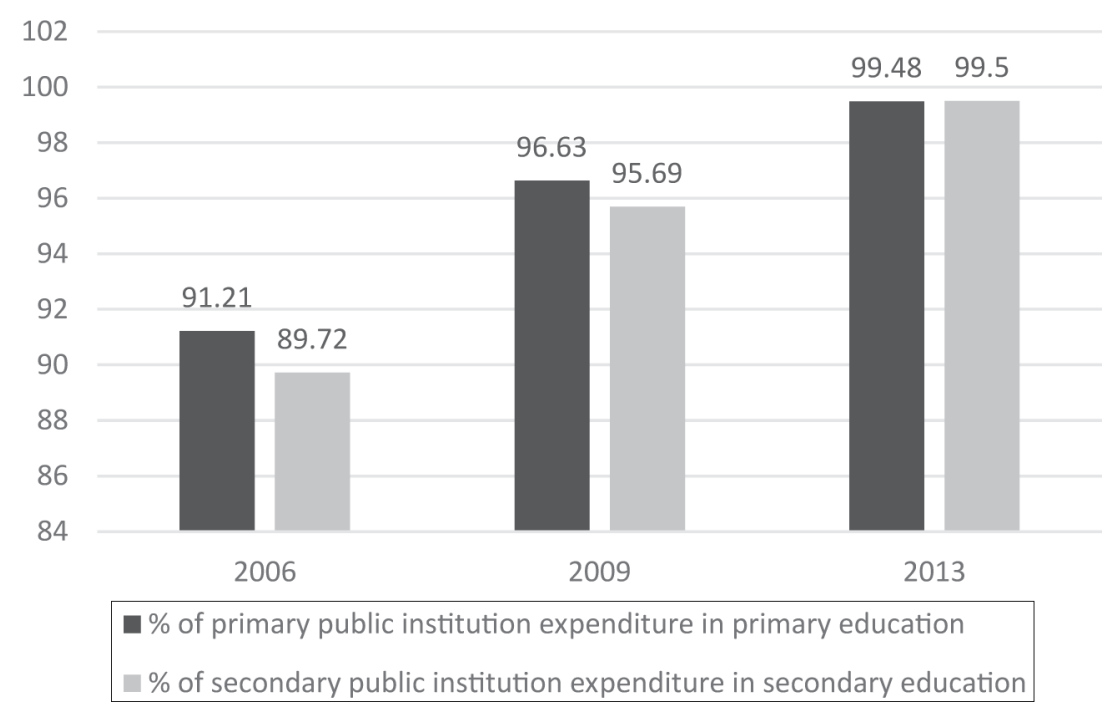


analyzing economic diversification since it reveals the characteristics and development of investments in an economy (Wadi and Bashayreh, 2018). Furthermore, gross fixed capital formation is a component of the GDP spending approach (Pettinger, 2016).

As can be seen from Table 1, between the years 2010 and 2017, the average $\mathrm{HHI}$ value is 0.2423, where maximum and minimum values of HHI are found in $2015(0.2489)$ and 2011 (0.2364).

The values of HHI over the year approximately fall in the moderately diversified range, which is $0.15<\mathrm{HHI}<0.25$ [3].

Furthermore, the line graph shows an upward trend in the HHI value; the HHI value was lowest in 2011, but then fluctuated from 2012 to 2014, until peaking in 2015.

As the HHI score falls into the 0.15 to 0.25 range over time, we can deduce that the UAE economy is somewhat diversified. The line graph 12 shows that, compared to 2010-11, the UAE's economic diversification status is deteriorating, with $\mathrm{HHI}>0.25$ indicating the least diversified range.

\subsection{DEA results}

The CCR model of the DEA approach was used to calculate the efficiency ratio of four information economy variables in this scenario. For this strategy, we needed input and output data, which we got from the WDI for the UAE from 2000 to 2020.

Table 2 lists the input and output variables for each of the elements, which are backed up by Afzal and Siddiqui (2009), Afzal and Lawrey (2012b), Afzal and Lawrey (2012c), Afzal and Lawrey (2014), Parcero and Ryan (2017), Phuong (2020), Ahmed and Abdalla Alfaki (2013) and Bashir (2013).

We also looked at efficiency ratios ranging from 0 to 1 , with 0 denoting inefficiency and 1 denoting the most effective ratio. We needed consistent data for all input and output variables for a given year to analyze this model. We were unable to process the data for the factor "Education and Human Resource," and as a result, the efficiency ratio could not be calculated. On a more positive note, we were able to collect all required data for three of the variables: economic incentive and institution regime, innovation system and information and communication technology, and we discovered that each factor's efficiency ratio was exactly 1 using the CCR model in MAXDEA software. As a consequence, we may deduce that these three variables are highly effective in the UAE.

\section{Overall discussion and contribution of this study}

According to HHI's empirical analysis, the UAE's economic diversity is moderate. The overall health of the UAE economy was examined in this study using data visualization,

\begin{tabular}{lc}
\hline Index & UAE ranking \\
\hline HDI (Human Development Index) & 0.846 \\
KEI (knowledge economic index) & 6.94 \\
Innovation & 41.99 \\
Economic incentive and institutional regime* & 6.75 \\
Education* & 4.90 \\
Innovation* & 6.69 \\
ICT* & 8.59
\end{tabular}

Notes: Most recent values as mentioned by Ahmed and Abdalla Alfaki (2013) *the four pillars of knowledge economy
Diversification toward knowledgebased economy 187

$-$ 


\begin{tabular}{|c|c|c|c|c|c|}
\hline \multirow{3}{*}{$\begin{array}{l}\text { REPS } \\
7,3\end{array}$} & \\
\hline & SL & Variable name & Description & $\begin{array}{l}\text { Short- } \\
\text { form }\end{array}$ & $\begin{array}{l}\text { Source } \\
\text { data }\end{array}$ \\
\hline & 1 & $\begin{array}{l}\text { GDP (constant, } \\
2010 \text { USD) }\end{array}$ & $\begin{array}{l}\text { It indicates the yearly gross domestic product of } \\
\text { each GCC country in USD, by considering base year } \\
2010\end{array}$ & GDPC & WDI-2021 \\
\hline \multirow[t]{4}{*}{188} & 2 & $\begin{array}{l}\text { International tourism, } \\
\text { number of arrivals }\end{array}$ & It covers the number of tourists coming each year & TA & WDI-2021 \\
\hline & 3 & $\begin{array}{l}\text { ICT goods exports ( } \% \\
\text { of total goods exports) }\end{array}$ & $\begin{array}{l}\text { It depicts the percentage of export of ICT goods } \\
\text { each year }\end{array}$ & ICTE & WDI-2021 \\
\hline & 4 & $\begin{array}{l}\text { Patent applications, } \\
\text { nonresidents }\end{array}$ & $\begin{array}{l}\text { Nonresident patent applications are from applicants } \\
\text { outside the relevant state or region }\end{array}$ & $\mathrm{PN}$ & WDI-2021 \\
\hline & 5 & $\begin{array}{l}\text { Patent applications, } \\
\text { residents }\end{array}$ & $\begin{array}{l}\text { Resident patent applications are those for which the } \\
\text { first-named applicant or assignee is a resident of the } \\
\text { state or region concerned }\end{array}$ & PR & WDI-2021 \\
\hline & 6 & $\begin{array}{l}\text { Scientific and technical } \\
\text { journal articles }\end{array}$ & $\begin{array}{l}\text { Number of scientific and technical journal articles } \\
\text { published each year }\end{array}$ & JA & WDI-2021 \\
\hline $\begin{array}{l}\text { Variable names and } \\
\text { data sources }\end{array}$ & 7 & $\begin{array}{l}\text { Fuel exports (\% of } \\
\text { merchandise exports) }\end{array}$ & $\begin{array}{l}\text { The percent of fuel exports out of total merchandise } \\
\text { exports }\end{array}$ & $\mathrm{FE}$ & WDI-2021 \\
\hline
\end{tabular}

DEA and the HHI approach. This led us to conclude that the amount of patent applications filed and journal articles published in the residence is critical for positively affecting the GDP. Ahmed and Abdalla Alfaki (2013) agreed with this conclusion, encouraging the government to place a premium on higher education and research. Furthermore, Figure 1 in the introduction section of this article reinforces this conclusion by noting that construction and building remained the greatest employer of labor throughout the time period. This is a significant finding because, as illustrated in Figure 1, low labor force participation in the education sector, combined with lower citizen participation in advanced education in the UAE, results in low scientific research and publications in Figure 3, low knowledge output as patent applications in Figure 7 and thus low ICT-based export indices in Table 3 for the UAE. In general, most of the UAE's population is expat, and the extent to which locals and expats contribute to the overall advancement of education remains an open question. Additionally, the lower rate of ICT exports dissuades UAE students from pursuing sciencerelated programs at higher education institutions. This results in a decrease in the number of scientists or researchers, as illustrated in this study (see Table 4).

Figure 7.

Patent applications; residents vs. nonresidents

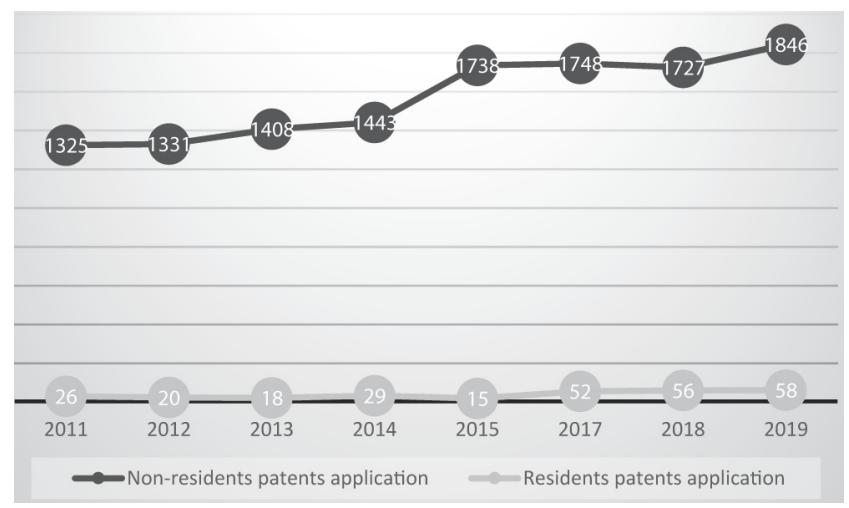


Over time, trade and repair services have increased employment opportunities for individuals. Other possible industries included real estate and manufacturing, hotels and restaurants, and community services, all of which outperformed the educational service industry. On the other hand, educational services have remained practically stable as a source of employment over time. In 2004, this industry employed roughly 20,000 people, and over twelve years later, in 2016, it employed 85,500 people, which is still low compared to other industries. More importantly, the increase in the number of employees (treated as input to the industry) can be misleading; the children of the growing number of expatriates may not be staying back in the country for higher education. Many of them actually go to the First World countries if they can afford, or through scholarships. So far, the country has not established itself as a competitive destination for higher education or highly capable scientific researchers (see Figure 8).

While the number of journal papers continues to increase, the number of researchers in the research and development sector has decreased (per million people). A beneficial outcome is that the government's research and development investment continue to expand each year (Phuong, 2020), which is consistent with Ahmed and Alfaki's advice (Ahmed and Abdalla Alfaki 2013). Residents apply for significantly fewer patents than nonresidents when two patent application variables are considered.

However, there is a surprising lack of negative correlation between nonresident patent applications and GDP; this could be because all goods and services manufactured by a nonresident are included in GNP (instead of GDP).

Although ICT products exports fluctuate, from 2017 to 2019, they contributed for an average of $7.43 \%$ of total goods exports. Additionally, this finding is consistent with Schiliro's (2013) finding that lower levels of technology transfer result in a negative trade balance.

The DEA technique to evaluate the components of the knowledge economy produces excellent findings, with efficiency values of one for the economic incentive and institutional regime, innovation systems and information and communication technology. This demonstrates that the UAE is on track to transform its economy into a knowledge-based, innovation-driven one; this conclusion is borne out by the authors' examination of the UAE's knowledge economy (Ahmed and Abdalla Alfaki, 2013; Ahmed, 2015; Phuong, 2020; Schiliro, 2013).

\section{Conclusion and policy issues}

The number of resident patent applications and journal articles has a large influence on GDP, whereas ICT exports have a tiny negative impact, according to this study. Furthermore, data

\begin{tabular}{lr}
\hline Year & HHI \\
\hline 2010 & 0.2367 \\
2011 & 0.2364 \\
2012 & 0.2477 \\
2013 & 0.2429 \\
2014 & 0.2428 \\
2015 & 0.2489 \\
2016 & 0.2446 \\
2017 & 0.2445
\end{tabular}

Source: Author's calculation

\section{Diversification toward knowledge- based economy}

189

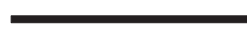


REPS

7,3

190

\begin{tabular}{|c|c|c|c|}
\hline Factor & Input & Output & Efficiency \\
\hline $\begin{array}{l}\text { Economic } \\
\text { Incentive and } \\
\text { Institutional } \\
\text { Regime }\end{array}$ & $\begin{array}{l}\text { Time required to start a business } \\
\text { (days) } \\
\text { Ease of doing business score } \\
(0=\text { lowest performance to } \\
100=\text { best performance) } \\
\text { Domestic credit to private sector } \\
(\% \text { of GDP) } \\
\text { Cost of business start-up } \\
\text { procedures (\% of GNI per capita) }\end{array}$ & $\begin{array}{l}\text { New business density } \\
\text { (new registrations per } \\
1,000 \text { people ages 15- } \\
64 \text { ) } \\
\text { New businesses } \\
\text { registered (number) }\end{array}$ & 1 \\
\hline $\begin{array}{l}\text { Education and } \\
\text { Human } \\
\text { Resource }\end{array}$ & $\begin{array}{l}\text { Technicians in R\&D (per million } \\
\text { people) } \\
\text { Labor force with basic education } \\
\text { (\% of total working-age } \\
\text { population with basic education) } \\
\text { Labor force with advanced } \\
\text { education ( } \% \text { of total working-age } \\
\text { population with advanced } \\
\text { education) } \\
\text { Current education expenditure, } \\
\text { primary (\% of total expenditure in } \\
\text { primary public institutions) } \\
\text { Current education expenditure, } \\
\text { secondary (\% of total expenditure } \\
\text { in secondary public institutions) }\end{array}$ & $\begin{array}{l}\text { Literacy rate, adult } \\
\text { total ( } \% \text { of people aged } \\
15 \text { and above) }\end{array}$ & $\begin{array}{l}\text { (Could not be found due } \\
\text { to lack of consistent data } \\
\text { for a particular year) } \\
\text { Inconclusive }\end{array}$ \\
\hline $\begin{array}{l}\text { Innovation } \\
\text { System }\end{array}$ & $\begin{array}{l}\text { Researchers in R\&D (per million } \\
\text { people) } \\
\text { Research and development } \\
\text { expenditure (\% of GDP) }\end{array}$ & $\begin{array}{l}\text { Scientific and technical } \\
\text { journal articles }\end{array}$ & 1 \\
\hline $\begin{array}{l}\text { Information and } \\
\text { Communication } \\
\text { Technology }\end{array}$ & $\begin{array}{l}\text { Secure Internet servers (per } 1 \\
\text { million people) } \\
\text { ICT spending (USD) }\end{array}$ & $\begin{array}{l}\text { Individuals using the } \\
\text { Internet (\% of } \\
\text { population) } \\
\text { High-technology } \\
\text { exports (current US\$) } \\
\text { ICT goods exports ( } \% \\
\text { of total goods exports) }\end{array}$ & 1 \\
\hline
\end{tabular}

Figure 8.

Line graph for the yearly values of $\mathrm{HHI}$

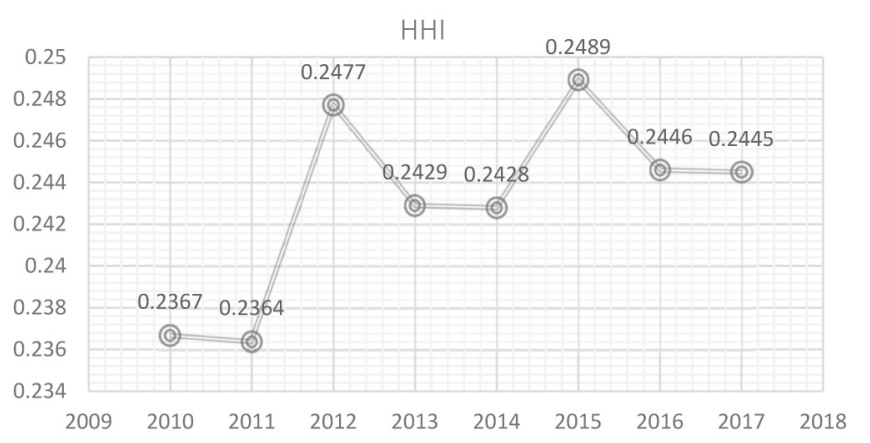


visualizations demonstrate that the number of researchers per million inhabitants in the UAE is decreasing, and that the UAE's ICT exports are inconsistent. This reflects reduced education spending in higher education, lesser worker involvement in the education sector from both home and abroad and poor participation in advanced studies by local students.

Another indicator that the UAE's economy is poised to transition to a knowledge-based economy is the DEA's flawless efficiency of three factors: economic incentive and institutional regime, innovation systems and information and communication technology.

The government of the UAE should make developing high-quality researchers a higher priority. The UAE government should create the ideal climate and teach residents to be better at this type of job because resident patent applications have a significant impact on GDP. The government should invest more in ICT and assist more enterprises in becoming ICT-based to expand its ICT exports.

\section{Limitation and future research}

This paper has some limitations due to data constraints. We needed data for both the input and output variables for a single year to compute the efficiency ratio of the education and human resource component; similarly, we were unable to calculate the ratio due to missing values.

Because of the constraints, the researchers are advised to do more research on this topic utilizing time series data and the VECM model, Granger causality test, ARIMA and exponential smoothing. In order to acquire a better grasp of the UAE's knowledge economy, the researchers are also motivated to determine the efficiency ratio of education and human resource variables.

\section{Notes}

1. (https://gulfnews.com/uae/education/uae-has-over-295000-higher-education-students-says-newreport-1.78194835)

2. (https://gulfnews.com/uae/education/uae-has-over-295000-higher-education-students-says-newreport-1.78194835)

3. Ranges are mentioned in section 3.2 .

\section{References}

Abu Dhabi Awards Dh40 Million In Research Funding To 53 Projects (n.d.), available at: https:// Gulfnews.Com/Uae/Abu-Dhabi-Awards-Dh40-Million-In-Research-Funding-To-53-Projects1.84232123 (accessed 04 January 2022).

Afzal, M.N.I. and Lawrey, R. (2012a), "Investigating World Bank knowledge assessment methodology (KAM) using data envelopment analysis (DEA): a study in the asean region", Research Journal of Science and IT Management, Vol. 1, pp. 33-38.

Afzal, M.N.I. and Lawrey, R. (2012b), "Knowledge-based economy (KBE) frameworks and empirical investigation of KBE input-output indicators for ASEAN", International Journal Of Economics And Finance, Vol. 4, pp. 13-22.

Afzal, M.N.I. and Lawrey, R. (2012c), "A measurement framework for knowledge-based economy (kbe) efficiency in asean: a data envelopment (DEA) window approach", International Journal of Business And Management, Vol. 7, pp. 57-68.

Afzal, M.N.I. and Lawrey, R. (2014), "Measuring the importance and efficiency of research and development expenditures in the transformation of knowledge-based economies: a case study of the asean region", International Journal of Asia-Pacific Studies, Vol. 10, pp. 33-47.

\section{Diversification toward knowledge- based economy}




\section{REPS}

7,3

Afzal, M.N.I. and Siddiqui, S.A. (2009), "Determnants of sustanable economc growth and knowledgebased economes (KBE): an investgaton on Bangladesh, Indonesa, Malaysa and Turkey", 9th International Conference On Knowledge, Economy and Management Proceedings, SarajevoBosnia and Herzegovina, 23-25 Haziran 2011, Saraybosna-Bosna Hersek.

Ahmed, A.Z.E. (2015), "The role of diversification strategies in the economic development for oildepended countries:-the case of UAE", International Journal of Business And Economic Development, Vol. 3, pp. 47-57.

Ahmed, A. and Abdalla Alfaki, I.M. (2013), "Transforming the United Arab Emirates into a knowledgebased economy: the role of science, technology and innovation", World Journal of Science, Technology and Sustainable Development, Vol. 10 No. 2, pp. 84-102, doi: 10.1108/ 20425941311323109.

Alshamlan, M.A., Fernandez, V.M. and Fernandez, M. (2021), "Foreign direct investment in the United Arab Emirates: a study on the main contributors", European Journal of Business and Management Research, Vol. 6, pp. 97-101.

Bashir, M. (2013), "Knowledge economy index (KEI) 2012 rankings for Islamic countries and assessment of KEI indicators for Pakistan", International Journal of Academic Research in Economics And Management Sciences, Vol. 2, p. 28.

Bayanat, A. (2020), Gross Fixed Capital Formation by Economic Sectors (Million Dirhams) - 2010-2017Gross Fixed Capital by Economic Sector - Million Aed - UAE Open Data Portal, Dubai.

Canada, S. (2017), Measuring Canadian Export Diversification, Statistics Canada, Montreal.

Charnes, A., Cooper, W.W. and Rhodes, E. (1978), "Measuring the efficiency of decision making units", European Journal of Operational Research, Vol. 2, pp. 429-444.

Cracau, D. and Lima, J.E.D. (2016), "On the normalized herfindahl-hirschman index: a technical note", International Journal On Food System Dynamics, Vol. 7, pp. 382-386.

Dima, A.M., Begu, L., Vasilescu, M.D. and Maassen, M.A. (2018), “The relationship between the knowledge economy and global competitiveness in the European union", Sustainability, Vol. 10, p. 1706.

Elder, J. and Serletis, A. (2010), "Oil price uncertainty", Journal of Money, Credit And Banking, Vol. 42, pp. 1137-1159.

Gmi (2021), United Arab Emirates Population Statistics (2021), Global Media Insight, available at: www.Globalmediainsight.Com/Blog/Uae-Population-Statistics/

Güney, T. (2019), "Renewable energy, non-renewable energy and sustainable development", International Journal of Sustainable Development and World Ecology, Vol. 26, pp. 389-397.

Haouas, I. and Heshmati, A. (2014), "Can the UAE avoid the oil curse by economic diversification?" IZA Discussion Paper No. 8003, Bonn, Germany, pp. 1-21.

Herfindahl, O. (1950), Concentration in the Steel Industry, Columbia University, New York, Ph. D. Dissertation.

Hirschman, A.O. (1980), National Power and the Structure of Foreign Trade, Univ of California Press, Oakland, CA.

Jones, R. (2001), Routledge Encyclopedia of International Political Economy, Routledge, London.

Mourdaa, R. and Atyeh, M.H. (2017), "Multiple regression analysis of diversification effect on GDP per capita: the case of UAE and Saudi Arabia", Asian Journal of Economic Modelling, Vol. 5, pp. 253-265.

Parcero, O.J. and Ryan, J.C. (2017), "Becoming a knowledge economy: the case of Qatar, UAE, and 17 benchmark countries", Journal of The Knowledge Economy, Vol. 8, pp. 1146-1173.

Pettinger, T. (2016), Gross Fixed Capital Formation, Economics Help, available at: www.Economicshelp. Org/Blog/6536/Economics/Gross-Fixed-Capital-Formation/ (accessed 16 May 2021).

Phuong, T.T. (2020), "Restructuring and economic diversification in the United Arab Emirates", International Journal of All Research Writings, Vol. 2, pp. 40-49.

Pickl, M.J. (2019), "The renewable energy strategies of oil majors-from oil to energy?”, Energy Strategy Reviews, Vol. 26, p. 100370. 
Sachs, J.D. and Warner, A.M. (2001), "The curse of natural resources", European Economic Review, Vol. 45, pp. 827-838.

Schiliro, D. (2013), “Diversification and development of the United Arab Emirates' economy”, Journal of Applied Economic Sciences, Vol. 8, pp. 228-239.

Shapira, P., Youtie, J., Yogeesvaran, K. and Jaafar, Z. (2006), "Knowledge economy measurement: methods, results and insights from the Malaysian knowledge content study", Research Policy, Vol. 35, pp. 1522-1537.

UAE, G.P. (2021), Travel and Tourism, Government Portal of UAE, Dubai.

UNFCC (2018), The Concept of Economic Diversification in the Context of Response Measures, UNFCC, Bonn.

Wadi, R.M.A. and Bashayreh, A. (2018), "Economic diversification in Bahrain”, International Journal of Economics and Financial Issues, Vol. 8, pp. 120-125.

Young, K.E. (2020), "Sovereign risk: gulf sovereign wealth funds as engines of growth and political resource", British Journal of Middle Eastern Studies, Vol. 47, pp. 96-116.

\section{Further reading}

Aburumman, A.A. (2020), "Covid-19 impact and survival strategy in business tourism market: the example of the UAE mice industry”, Humanities And Social Sciences Communications, Vol. 7, pp. 1-11.

Afzal, M.N.I. (2014), "An empirical investigation of the national innovation system (NIS) using data envelopment analysis (DEA) and the tobit model", International Review of Applied Economics, Vol. 28, pp. 507-523.

Ahmed, E.M. and Ridzuan, R. (2013), "The impact of ICT on east asian economic growth: panel estimation approach", Journal of The Knowledge Economy, Vol. 4, pp. 540-555.

Alhowaish, A.K. (2016), "Is tourism development a sustainable economic growth strategy in the long run? Evidence from GCC countries”, Sustainability, Vol. 8, p. 605.

Amavilah, V.H.S., Asongu, S. and Andres, A. (2014), "Globalization, peace and stability, governance, and knowledge economy", African Governance and Development Institute Wp/14/012, pp. 1-42.

Bakar, N.M.A. and Midi, H., "The applications of robust estimation in fixed effect panel data model", 1st AECH Global Conference (Agc 2018), 2019, Atlantis Press, pp. 341-346.

Banker, R.D., Charnes, A. and Cooper, W.W. (1984), "Some models for estimating technical and scale inefficiencies in data envelopment analysis", Management Science, Vol. 30, pp. 1078-1092.

Greenaway, D., Morgan, W. and Wright, P. (1999), "Exports, export composition and growth”, Journal Of International Trade and Economic Development, Vol. 8, pp. 41-51.

Keene, O.N. (1995), "The log transformation is special”, Statistics In Medicine, Vol. 14, pp. 811-819.

Nguyen, T.V. and Pham, L.T. (2011), "Scientific output and its relationship to knowledge economy: an analysis of ASEAN countries", Scientometrics, Vol. 89, pp. 107-117.

Salter, B. (2009), "State strategies and the geopolitics of the global knowledge economy: china, India and the case of regenerative medicine", Geopolitics, Vol. 14, pp. 47-78.

Wiseman, A.W. and Anderson, E. (2012), "ICT-integrated education and national innovation systems in the Gulf cooperation council (GCC) countries", Computers and Education, Vol. 59, pp. 607-618.

\section{Corresponding author}

Munshi Naser Ibne Afzal can be contacted at: munshinaser-eco@sust.edu
Diversification toward knowledgebased economy 